\title{
SUBSURFACE CONTAMINATION WITH PETROLEUM PRODUCTS IS A THREAT TO GROUNDWATER QUALITY
}

\author{
М. Огняник, Н. Парамонова, О. Шпак \\ ПРОБЛЕМА ЯКОСТІ ПІДЗЕМНИХ ВОД В УКРАЇНІ У ЗВ'ЯЗКУ ІЗ ЗАБРУДНЕННЯМ \\ ГЕОЛОГІЧНОГО СЕРЕДОВИЩА НАФТОПРОДУКТАМИ
}

\begin{abstract}
Забруднення геологічного середовища нафтопродуктами являє собою загрозу якості підземних вод на всій території України. Проаналізовані методи пошуків та розвідки забруднених нафтопродуктами ділянок. Вивчались міграція нафтопродуктів у геологічному середовищі та методи відновлення. Ефективність вилучення авіаційного керосину вивчалась в лабораторних умовах у піщаній колонні. Розрахована безпечна відстань від джерела забруднення до водозабірних свердловин для різних гідрогеологічних умов за допомогою математичного моделювання. Розглянуто випадок забруднення питних підземних вод нафтопродуктами у м. Херсон.
\end{abstract}

Ключові слова: забруднення, нафтопродукти, підземні води, методи вилучення, фізичне та математичне моделювання.

Загрязнение геологической среды нефтепродуктами является угрозой качеству подземных вод на всей территории Украины. Проанализированы методы поисков и разведки загрязненных нефтепродуктами участков. Изучалась миграция нефтепродуктов в геологической среде и методы восстановления. Эффективность извлечения авиационного керосина изучалась в лабораторных условиях на песчаной колонне. Рассчитано безопасное расстояние от источника загрязнения до водозаборных скважин с помощью математического моделирования. Рассмотрен случай загрязнения питьевых подземных вод нефтепродуктами в г. Херсон.

Ключевые слова: загрязнение, нефтепродукты, подземные воды, методы извлечения, физическое и математическое моделирование

Subsurface contamination with oil poses a threat to groundwater quality on the whole territory of Ukraine. The methods of search and prospecting of contaminated plums were analyzed. Oil behaviour in the subsurface and the methods of remediation were studied. The effectiveness of aviation kerosene removal was examined in a sandy column by physical modelling. Nonhazardous distances from a contamination source to water-supply wells were determined for different hydrogeological conditions by mathematical modelling. The case of drinking groundwater contamination with oil in Kherson City is examined.

Keywords: contamination, oil, groundwater, remediation methods, physical and mathematical modeling

\section{INTRODUCTION}

Subsurface contamination with petroleum products (oil) has become one of the most important environmental problems on the whole territory of Ukraine. Taking into consideration wide distribution of petrol stations, fuel storehouses, pipelines, etc., subsurface contamination with oil is supposed to spread to large areas. Groundwater contamination with oil is the most threatening because groundwater is the main source of drinking water supply. Maximum contaminant levels are accepted to be extremely low for oil (0.001-0.1 $\left.\mathrm{mgl}^{-1}\right)$ and in one or two orders of magnitude less than solubility so even small oil concentrations render water unfit for domestic use and hazardous to health. At present, groundwater is contaminated in a number of cities and towns in Ukraine such as Kherson, Lugansk, Poltava, Lutsk, Uzin, and others. More than 120 large water-supply-well systems are located within contaminated sites.
There is an environmental risk on the whole territory of Ukraine (see fig. 1). This situation is considered to be critical with grave consequences in the nearest future. In order to recover from the crisis, it is necessary to liquidate or control current contamination cases and prevent potential ones.

\section{GOALS AND TASKS}

The primary tasks are search and prospecting of contaminated plums to estimate a size, a volume and a stage of contamination, oil distribution in the subsurface and an effect on surrounding wells, ponds, rivers, etc. The complex estimation of subsurface contamination at the territories of oil-products objects must be the first stage of remediation.

Searching includes detection of contaminated plumes within large areas exposed to oil contamination. A direct method of studying contamina- 


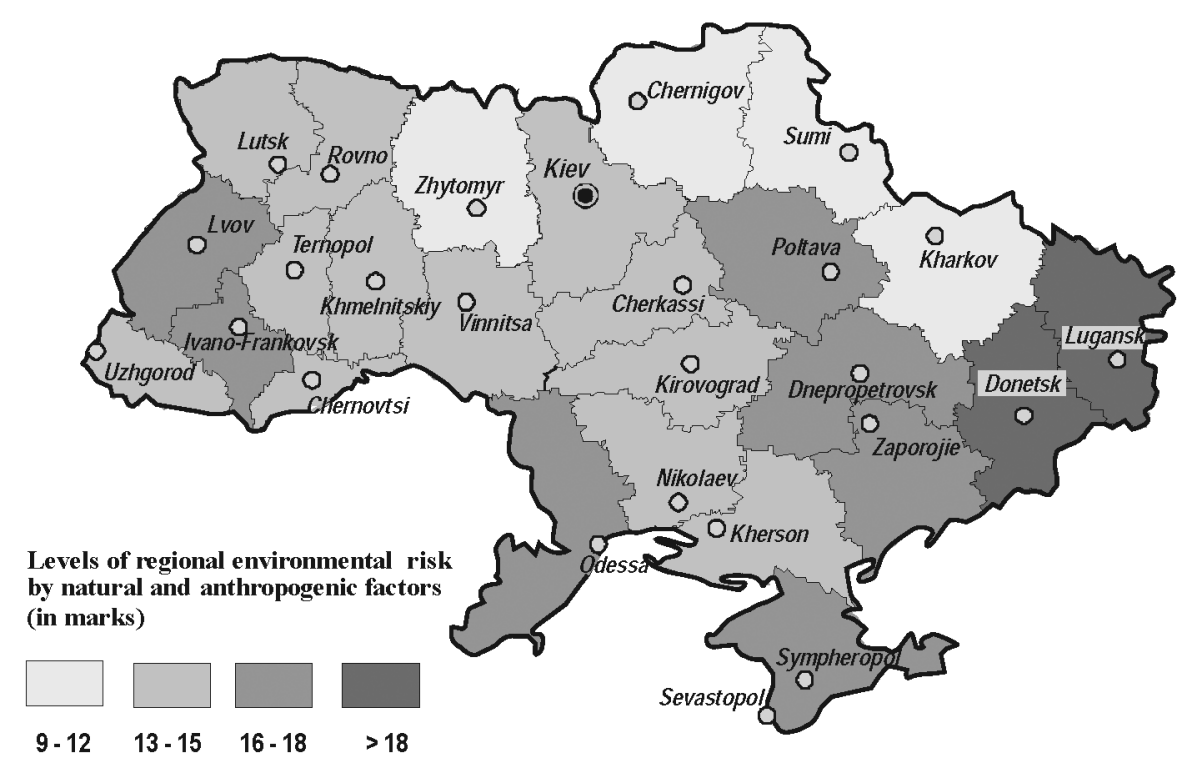

Fig. 1. The scheme of complex regional environmental risk of Ukraine [5]

tion cases (well drilling and sampling) is rather expensive and can promote oil spreading in the subsurface. The attempt to use a geophysical surface method based on measurements of electromagnetic conductivity failed to provide correct results. Contaminated plumes revealed by this method within Uzin military airbase in Kiev region did not correspond to the map made by well drilling and sampling [4]. However, we concluded that mapping and monitoring can be sped up measuring hydrocarbon concentrations in samples near a well in situ. For this a portable chromatograph (less $5 \mathrm{~kg}$ ) can be used to measure hydrocarbon contents in water, soil and air for one minute. Such an apparatus developed on basis of a flameionization detector was tested.

\section{OIL BEHAVIOUR IN THE SUBSURFACE AND METHODS OF REMEDIATION}

Light oil with a density less than $1 \mathrm{~g} / \mathrm{cm}^{3}$ enters in the unsaturated zone and moves down due to gravitation. At this, light oil undergoes the influence of physical and chemical properties such as dissolution, evaporation, sorption and biodegradation. A three-fluid "water-oil-air" system is formed in the unsaturated zone where water and oil are retained due to capillary forces depending on dispersivity, soil moisture and fluid interfacial tension. An oil lens is formed on a low permeable layer or a groundwater table (see fig. 2). The core of the lens contents mobile oil that can move due to hydraulic gradient and flow into a well. Upper the core the unsaturated oil capillary fringe is formed due to the interfacial air-oil tension while under the core the saturated capillary fringe is formed due to the interfacial oil-water tension. Upper the lens a film-drop zone remains after gravitational oil draining while under the lens a retained oil zone is formed due to oil spreading or water table rise. In the aquifer the lens is surrounded with dissolved oil [1].

It is necessary to define oil distribution and volume in each zone because oil behaviour and methods of oil recovery are different in them [3].

In the film-drop zone oil is retained by soil and can migrate as a water solution or an emulsion. In the unsaturated capillary fringe oil can be thrown down into the saturated zone due to the weight of an oil column only or together with a water column accumulated on top if the weight exceeds capillary forces.

In the saturated zone mobile oil can spread on a water table and flow into surrounding wells, ponds, rivers, etc. Such cases were observed in wells near Uzin and Lutsk airbases [2], and in the Ros River near Bila Tserkva airbase [7] located from hundred metres to one kilometre away from contamination sources. Mobile oil can be recovered by pumping and open or closed drainage. However, no more than forty percent of mobile oil is recovered by these methods [5]. Thus, 14514 tones of kerosene remained in soil after pumping at Uzin airbase and 5917 tones of kerosene remained after pumping at Priluky airbase [4]. After drainage of mobile oil the most part of this zone passes into the capillary oil-water zone and then into the oil-entrapped-in-water zone. This oil can not be recovered mechanically. It is necessary to reduce surface tension due to pumping of surfactant species that can also contaminate ground- 


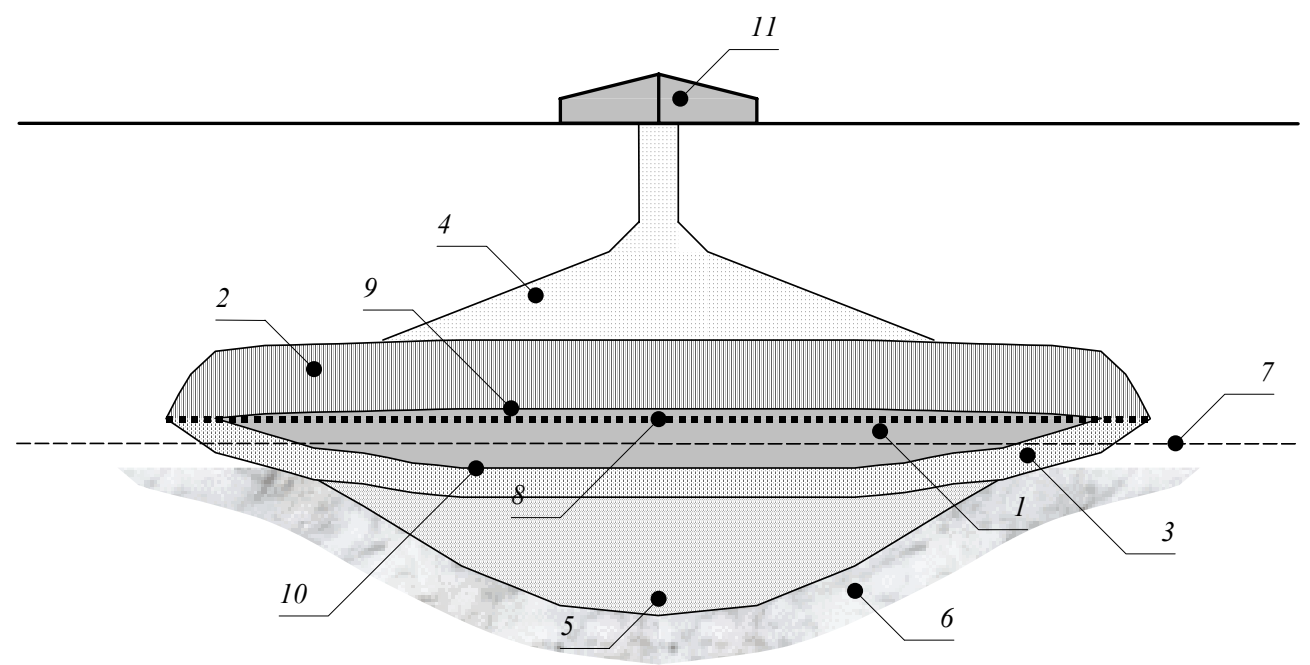

Fig. 2. An oil lens in homogeneous isotropic sediments

1 - mobile oil; 2 - the air-oil capillary zone; 3 - the oil-water capillary zone; 4 - residual oil as films or drops; 5 - retained oil in the saturated zone; 6 - dissolved oil; 7 - a water table; 8 - a buoyancy table; 9 - an air-oil level; 10 - an oil-water level; 11 - a contamination source

water. Therefore, remediation based on microbial biodegradation is an optimal method for contamination removal. Aerobic biodegradation is applied in near-surface layers and anaerobic biodegradation is applied in deep layers.

\section{PHYSICAL MODELLING OF REMEDIATION}

The effectiveness of aviation kerosene removal was examined by all these methods using physical modelling at the laboratory. A column filled with fine sand imitated the porous subsurface containing a kerosene lens in which $220.34 \mathrm{~cm}^{3}$ of kerosene were in the saturated zone and $80.36 \mathrm{~cm}^{3}$ of kerosene were in the unsaturated zone. First of all, kerosene was removed from the saturated zone due to gravitational drainage, which corresponded to pumping with a gradient $1.49 \mathrm{~cm}^{3}$ of kerosene $(22 \%$ of all the kerosene in the saturated zone) flew out and after that $251.7 \mathrm{~cm}^{3}$ of kerosene retained by capillary forces remained in the sandy column. Then, there was an attempt to remove the rest of kerosene by vacuuming (-7.2 m of water column). At this, $91 \mathrm{~cm}^{3}$ (36.15\%) of kerosene were removed.

We tried to wash out kerosene remained in soil imitating water input in the unsaturated zone and water output from the aquifer. The water input of $980 \mathrm{~cm}^{3}$, which is six times greater than the kerosene amount, with the velocity of $1.64 \mathrm{~cm} /$ hour resulted in the kerosene output of $35 \mathrm{~cm}^{3}$. $125.7 \mathrm{~cm}^{3}$ of kerosene remained in pores less than $3 \mu \mathrm{m}$. The output of hot water $\left(80^{\circ} \mathrm{C}\right)$, which must have reduced kerosene surface tension, resulted in the kerosene output of $10 \mathrm{~cm}^{3}$ only. During filtration water temperature sharply decreased.

Biopreparation "Simbinal" developed by the Institute of Botany of the National Ukrainian Academy of Sciences (www.biorosinfo.ru/papers-society/Strategy_Bioindustry.pdf) was used to remove kerosene from pores less than $3 \mu \mathrm{m}$. "Simbinal" input resulted in the value of saturation 0.7. After eleven days the amount of kerosene decreased in $19.35 \%$ and after 25 days - in $7 \%$. Then, a new portion of kerosene was added into the column. After 30 days the amount of kerosene decreased in $6.79 \%$ only and $12.9 \%$ of kerosene remained in sand. The results of the experiment showed that as the content of kerosene decreased the velocity of biodegradation decreased too. Therefore, all the kerosene was not removed from sand for two months.

Table 1 demonstrates the results of the physical modelling.

\section{MATHEMATICAL MODELLING OF DISSOLVED OIL SPREADING}

In case of long-term contamination sources a zone of dissolved light oil around a lens can spread in an aquifer at large distances especially when large water-supply well systems increase hydraulic gradient accelerating a contaminated water flow. Nonhazardous distances from a contamination source at which water-supply wells remain uncontaminated for 27 years (the term of well exploitation) were calculated 
Table 1. The results of physical modelling of aviation kerosene recovery

\begin{tabular}{|l|c|c|c|}
\hline Method of recovery & recovery, $\%$ & rest, $\%$ & Annotation \\
\hline Gravitational draining & $22.2 / 16.3$ & $77.8 / 83.7$ & $\begin{array}{c}\text { Of the volume in the saturated } \\
\text { zone / of all volume }\end{array}$ \\
\hline Vacuumization & 36.15 & 63.85 & Of the retained volume \\
\hline Washing-out by cold water & 13.9 & 49.95 & $-/ /-$ \\
\hline Washing-out by hot water & 4.0 & 45.95 & $-/ /-$ \\
\hline Biodegradation: «Simbinal»: & & & $-/ /-$ \\
\hline I portion: after 11 days & 19.35 & 26.6 & $-/ /-$ \\
\hline after 25 days & 7.0 & 19.6 & $-/ /-$ \\
\hline II portion after 15 days & 6.7 & 12.9 & \\
\hline
\end{tabular}

Table 2. Calculated nonhazardous distances from a contamination source to water-supply wells

\begin{tabular}{|c|c|c|}
\hline Hydrogeological conditions & Parameters* & Nonhazardous distance, m \\
\hline \multicolumn{3}{|l|}{ I. Unconfined aquifer } \\
\hline $\begin{array}{l}\text { la. High permeable sediments } \\
\text { (sand, shingle) }\end{array}$ & $\begin{array}{l}\text { 1. } k=5.0 ; n_{a}=0.15 \\
\text { 2. } k=30.0 ; n_{a}=0.20 \\
\text { 3. } k=100.0 ; n_{a}=0.25\end{array}$ & $\begin{array}{l}2000 \\
3500 \\
6700\end{array}$ \\
\hline Іб. Low permeable sediments & $\begin{array}{l}\text { 1. } k=1.0 ; n_{a}=0.10 \\
2 . k=0.10 ; n_{a}=0.05\end{array}$ & $\begin{array}{l}550 \\
300\end{array}$ \\
\hline IB. Two-layer sediments & $\begin{aligned} & \text { 1. } k=0.10 ; n_{a}=0.05 \text { (upper) } \\
& k=10.0 ; n_{a}=0.15 \text { (lower) } \\
& \text { 2. } k=25,0 ; n_{a}=0.20\end{aligned}$ & $\begin{array}{l}2800 \\
3500\end{array}$ \\
\hline \multicolumn{3}{|l|}{ II. Interstratal unconfined aquifer } \\
\hline Overlying low-permeable layer & $\mathrm{k} / \mathrm{m}<3 \times 10^{-6}$ & \\
\hline Aquifer & $k>30.0$ & $2000 * *$ \\
\hline \multicolumn{3}{|l|}{ III. Confined aquifer } \\
\hline $\begin{array}{l}\text { Illa. Overlain with a continuous low- } \\
\text { permeable layer }\end{array}$ & $\begin{array}{l}\text { 1. } \mathrm{k} / \mathrm{m}<1 \times 10^{-6} ; \mathrm{k} \geqslant 70.0 \\
\text { 2. } \mathrm{k} / \mathrm{m}=1 \times 10^{-5}-1 \times 10^{-6} ; \mathrm{k} \geqslant 70.0\end{array}$ & $\begin{array}{c}2500 \\
2500-7000\end{array}$ \\
\hline $\begin{array}{l}\text { ІІІб. Overlain with a discontinuous } \\
\text { low-permeable layer }\end{array}$ & $k=30.0-70.0$ & $5000-20000 * * *$ \\
\hline \multicolumn{3}{|c|}{$\begin{array}{l}* \mathrm{k}-\text { a hydraulic conductivity, } \mathrm{m} / \text { day; na }- \text { active porosity; } \mathrm{k} / \mathrm{m}-\text { leakance, } 1 / \mathrm{day} ; * *-\text { if } \mathrm{k} / \mathrm{m} \text { increases and } \mathrm{k} \\
\text { decreases, a nonhazardous distance reaches the values in the unconfined aquifer; } * * *-\text { a nonhazardous distance } \\
\text { depends on the location of "gaps" in a low-permeable layer. }\end{array}$} \\
\hline
\end{tabular}

using mathematical modelling (Table 2). A number of profile tasks were solved for typical hydrogeological conditions using PMWIN program complex. Water flow and oil masstransport in aquifers were modelled. Stationary problem was solved. Tabular hydrogeological parameter values were used. Distances from a source at which contamination does not reach wells were determined for 5, 10 and 27 years. The results of modelling provide to predict groundwater contamination, plan monitoring and remediation.

A significant contamination case of a large water-supply well system in a confined aquifer overlain with a discontinuous low-permeable layer occurred in Kherson City where water-supply wells are located four kilometres away from a refinery [6]. Dissolved oil transport in a high-permeable limestone aquifer was imitated using PMWIN program complex. Modelling results showed that aquifer contamination occurred due to "gaps" in an overlying layer and oil reached water-supply wells in two and half years.

\section{CONCLUSIONS AND RECOMMENDATIONS}

There is an environmental risk from oil-products objects on the whole territory of Ukraine. It is necessary to liquidate or control current contamination cases and prevent potential cases.

The complex estimation of subsurface contamination at the territories of oil-products objects must be the first stage of remediation.

Under a long-term contamination source a mobile oil lens is formed on a water table and can flow into surrounding wells, ponds, rivers, etc. No more than forty percent of mobile oil is recovered by pumping. The rest of oil is retained in soil and it can not practically be removed.

In aquifers dissolved oil can spread at large distances from contamination sources, which 
poses a sufficient threat for drinking water-supply well systems.

Monitoring of groundwater quality must be carried out at drinking water-supply well systems. In case of groundwater contamination with oil it is necessary to reveal the cause of contamination and carry out remediation. Designing new watersupply well systems, the impact of oil-products objects should be taken into consideration.

1. Baehr A.L. and M.Y. Corapcioglu. (1987) A compositional multiphase model for groundwater contamination by petroleum products. Water resources research. Vol. 23. 191-200.

2. Bricks A., Negoda Y., Shpak O. (2002) Using computer modelling for predictions of groundwater contamination with petroleum products in the area of Lutsk aerodrome and development of actions to localize contamination. Proceedings of “IAP 2002”, Hungary. 99.

3. Farr A.M., Houghtalen R.J., McWhorter D.B. (1990) Volume estimation of light nonaqueous phase liquids in porous media. Ground Water. №1. 48-56.
4. Ognianik N, Shpak O., Golub G., Negoda Y., Nasedkina O. (2003) The estimation of subsurface contamination with oil within the airbase (in Russian). Proceedings of "Sergeevskie chtenia", Moscow. 342-348.

5. Ognianik N.S., Paramonova N.K., Bricks A.L., Pashkovskiy I.S., Konnov D.V. (2006) The fundamentals of studying of subsurface contamination with light petroleum products (in Russian). Kiev. 278 p.

6. Shpak O. (2006) Groundwater contamination with oil within large water-supply well systems (in Ukrainian). Proceedings "Modern areas of geology in Ukraine”, Kiev. 159-167.

7. Shpak O., Ognianik N., Negoda Y., Golub G. (2003) Assessment of military airbase impact on the environment. Proceedings of CERECO'2003, Hungary. 366-369.

8. www.biorosinfo.ru/papers-society/ Strategy_Bioindustry.pdf

The Institute of Geological Sciences of the NAS of Ukraine, Kyiv

E-mail: gwp_ign@gwp.org.ua,shpak_lena@yahoo.com 